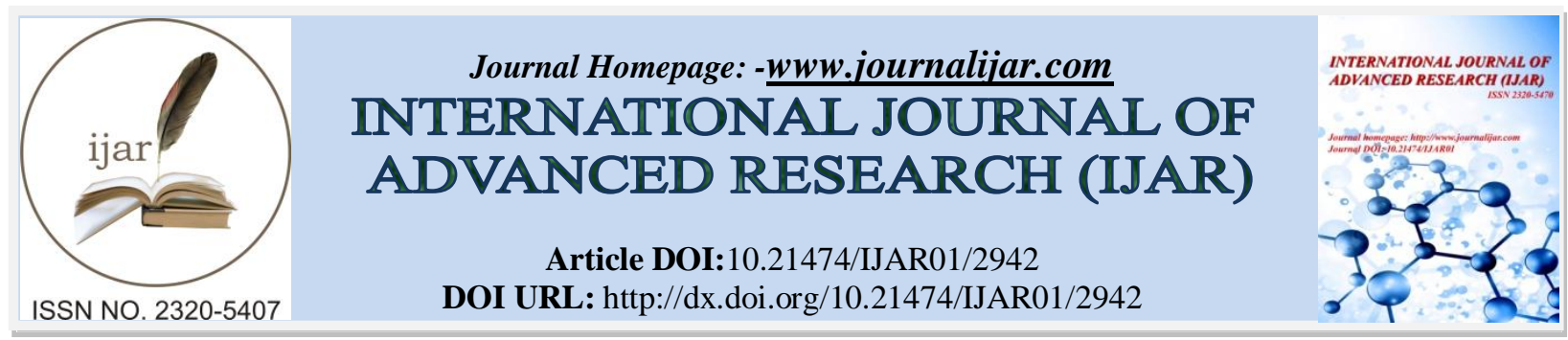

RESEARCH ARTICLE

\title{
VITAMIN D3 IMPROVES LIVER FUNCTIONS IN EXPERIMENTALLY INDUCED TYPE II DIABETES MELLITUS IN WISTAR RATS
}

\author{
Noha N. Lasheen ${ }^{1}$ and Nashwa El-Khazragy ${ }^{2}$ \\ 1. Lecturer of Physiology, Faculty of Medicine, Ain Shams University. \\ 2. Lecturer of Clinical Pathology, Faculty of Medicine, Ain Shams University Cairo, Egypt.
}

\section{Manuscript Info}

\section{Manuscript History}

Received: 25 November 2016

Final Accepted: 27 December 2016

Published: January 2017

Key words:-

Diabetes Mellitus, Liver, Mitochondrial

NAD+, Stearoyl-CoA desaturase1,

Vitamin D3

\section{Abstract}

Background and Aim: Vitamin D3 could ameliorate the effects of type 2 diabetes mellitus; however, liver changes in diabetes needs more studies and to highlight changes in liver cell mitochondrial NAD+ and Stearoyl-CoA desaturase 1 (SCD1).

Materials and Methods: Forty adult Wistar rats, of both sexes, were randomly allocated into equal groups of control, vitamin D3 nondiabetic, diabetic, type 2 diabetic and vitamin D3 treated diabetic groups. At the end of the study, all rats were anaesthetized by i.p. Pentoparbitone (40 mg/kg B.W). Fasting blood glucose level was measured by rat tail, then after aortic cannulation, the separated plasma was used for determination of lipid profile, liver functions and insulin level. HOMA-IR and atherogenic indices were calculated. Liver specimens were used for detection of SCD1 gene expression by Real time PCR and mitochondrial NAD ${ }^{+}$.

Results: Glycemic parameters and plasma liver enzymes, liver mitochondrial $\mathrm{NAD}^{+}$were significantly elevated in the diabetic group compared to the control group, and were significantly lowered in vitamin D3 treated diabetic group compared to the diabetic group. The diabetic group had dyslipidemia compared to the control group, while lipid profile was improved in vitamin D3 treated diabetic group compared to the diabetic group. SCD1 gene expression in liver cells was downregulated in both diabetic groups (untreated and treated) compared to the control group.

Conclusion: Vitamin D3 reversed the damaging diabetic effects on liver functions efficiently, probably by ameliorating oxidative stress, however, it altered SCD1 gene expression and regulated its effect on diabetes to lesser extent.

Copy Right, IJAR, 2016,. All rights reserved.

\section{Introduction:-}

Diabetes mellitus is a worldwide problem, and increases in incidence and prevalence (Danaei et al., 2011). The relation between vitamin D and type 1 diabetes mellitus has been extensively studied in humans and animals, and it could be due to the immunomodulatory actions of vitamin D(Stene et al., 2000; Gregori et al., 2002; Mathieu et al., 2005; Luong et al., 2005). 
For type 2 diabetes mellitus to develop, impaired pancreatic $\beta$ cell function and insulin resistance are often present. The prevalence of type 2 diabetes rises in obesity, which is often associated with hypovitaminosis D (Palomer et al., 2008). Vitamin D is efficiently deposited in body fat stores decreasing its bioavailability, thereby many obese persons could be chronically vitamin D deficient (Holick, 2004). Zeitz et al. (2003) reported that vitamin D receptor could be expressed in $\beta$ cells. Thus, vitamin D deficiency could decrease insulin secretion in rats and humans, and its replenishment could improve $\beta$-cell function and glucose tolerance (Boucher et al., 1995). Also, it was suggested that vitamin D insufficiency could cause insulin resistance probably by elevated TNF- $\alpha$ level which is a cytokine inversely related to $25(\mathrm{OH})$ vitamin D (Hotamisligil and Spiegelman, 1994). In addition,Ortlepp et al. (2003) reported that alteration in vitamin D receptor and vitamin D-binding protein could affect glucose tolerance and insulin secretion. Ogunkolade et al. (2002) mentioned that vitamin D could affect type 2 diabetes mellitus through either controlling plasma calcium level, which regulates insulin synthesis and secretion, or directly on pancreatic $\beta$ cell function.

In addition,DeLuca and Cantorna(2001) mentioned that liver cells had cytosolic or nuclear and/or membranebound vitamin D receptors. However, few researchers studied the impact of vitamin D supplementation on altered liver functions in type 2 diabetes mellitus(Yang et al., 2016).

Fat metabolism changes in type 2 diabetes mellitus were proved to be present(Shulman, 2000). Stearoyl-CoA desaturase (SCD) is the rate limiting enzyme catalyzing the biosynthesis of monounsaturated fatty acids, the substrates for triglycerides synthesis and formation of cholesterol esters and phospholipids.SCD1 is the main SCD isoform expressed in liver (Dobrzyn and Dobrzyn, 2006). Abnormal monounsaturated fatty acid production could cause many diseases such as obesity, diabetes and cancer. Therefore, it is of value to study SCD1 expression in normal and disease states (Miyazaki et al., 2003). Although many studies are present regarding the effect of type 2 diabetes mellitus on SCD, little is known about the effect of vitamin D on the SCD gene expression in type 2 diabetes mellitus.

On the other hand, oxidative stress could be present in type 2 diabetes mellitus resulting in the development of diabetic complications in many organs(Giacco and Brownlee, 2010). However, changes in mitochondrial $\mathrm{NAD}^{+}$in liver cells in type 2 diabetes were not extensively studied. Therefore, it is valuable to study the draw backs of diabetes mellitus (type 2) on liver functions and to elucidate the changes in SCD1 gene expression and mitochondrial $\mathrm{NAD}^{+}$in the liver tissues; in addition to study the possible effects of vitamin $\mathrm{D} 3$ in type 2 diabetes mellitus.

Aim of the work:-

This study was performed to demonstrate the effects of vitamin D3 treatment on liver functions in type 2 diabetic rats and to highlight the changes in SCD1 gene expression and mitochondrial $\mathrm{NAD}^{+}$in liver cells.

\section{Materials and Methods:- Experimental Protocol: \\ Animals:}

This study was carried out on 40 adult Wistar rats, of both sexes, initially weighing 160-200 gm, purchased from animal farm from Helwan, Cairo, Egypt. Animals were kept in the Medical Research Center Animal House, Faculty of Medicine, Ain Shams University under standard conditions of boarding and feeding, with free access to water, ad libitum, throughout the whole period of the study. Rats were left for 7 days as a period of acclimatization, during which regular normal diets were introduced daily at 8 a.m., in the form of milk, bread and vegetables.

\section{Experimental Protocol:-}

Rats were randomly allocated into the following groups:-

Group I: Control group $(n=10)$ : received a single i.p. injection of saline in equivalent dose of Streptozotocin and also equivalent dose of $1,25(\mathrm{OH})_{2} \mathrm{D}_{3}$ each 2 days for 8 weeks.

Group II: Vitamin D3 Supplemented Non-Diabetic group ( $\mathrm{n}=10)$ : which received i.p. injection of $5 \mu \mathrm{g} / \mathrm{kg} 1$, $25(\mathrm{OH})_{2} \mathrm{D}_{3}$, each 2 days for 8 weeks, only without induction of diabetes mellitus (Yin et al., 2012). 
Group III: Type 2 Diabetic group $(\mathrm{n}=10)$ : which were fed high fat diet for 2 weeks followed by single i.p. injection of Streptozotocin (Sigma Co.) in a dose of $35 \mathrm{mg} / \mathrm{kg} \mathrm{B}$.W. dissolved in $2 \mathrm{ml}$ of $0.05 \mathrm{M}$ citrate buffer (Srinivasan et al., 2005).

Group IV: Vitamin D3 Treated Diabetic group $(n=10)$ : which were rendered diabetic by the same method as the diabetic group, and then they were treated with i.p. injection of $5 \mu \mathrm{g} / \mathrm{kg} 1,25(\mathrm{OH})_{2} \mathrm{D}_{3}$, each 2 days for 8 weeks (Yin et al., 2012).

Induction of Diabetes Mellitus Type 2:-

High fat diet, introduced to diabetic groups, was prepared by adding butter, to increase its fat content to $16-17 \%$. Analytical composition of butter used in the present study was in accordance with Holland and Welch (1992). After Streptozotocin injection into overnight fasted rats, they had free access of food and water, and were given 5\% glucose solution after 6 hours of Streptozotocin injection to drink overnight to counter hypoglycemic shock. The diabetic state was assessed by measuring the non-fasting blood glucose levels from rat tail $72 \mathrm{hrs}$ after Streptozotocin injection. The rats with blood glucose level above $250 \mathrm{mg} / \mathrm{dl}$ were selected for the experiment and considered as diabetics (Zhang et al., 2006).

On the day of sacrifice, overnight fasted rats were weighed and anaesthetized by i.p. injection of pentobarbitone, in a dose of $40 \mathrm{mg} / \mathrm{kg}$ B.W. Fasting blood glucose (FBG) was measured in a blood drop from the rat tail by GlucoDrTM SuperSensor Test Meter, AGM- 2200, Korea. A midline abdominal incision was made and the abdominal aorta was cannulated to collect aortic blood in 2 tubes; EDTA containing tube for subsequent determination of HbA1c in whole blood sample and a heparinized tube, which were centrifuged and the separated plasma was stored at $-80{ }^{\circ} \mathrm{C}$ for later determination of insulin level to calculate homeostasis model assessment of insulin resistance (HOMA-IR), $\gamma$-GT activity and levels of AST, ALT in addition to lipid profile. Liver specimens were also stored at $-80^{\circ} \mathrm{C}$ for later determination of mitochondrial $\mathrm{NAD}^{+}$and SCD1 gene expression.

\section{Determination of Plasma Insulin Level:-}

was performed according to Flier et al. (1979), using enzyme linked immunosorbent assay (ELISA) technique kits supplied by Insulin ELISA kit supplied by DRG .

Homeostasis Model Assessment- Insulin Resistance (HOMA-IR) $=$ [fasting plasma insulin $(\mu \mathrm{U} / \mathrm{mL}) \times$ fasting plasma glucose (mmol/L) /22.5] (Salgado et al., 2010). HbA1cwere quantified by HPLC(Jeppsson et al.; 2002).

Liver enzymes levels [Aspartate Aminotransferase (AST), Alanine Aminotransferase (ALT)] and Gamma Glutamyl Transferase $(\gamma$-GT) activity were determined colorimetric assay according to Reitman and Frankel (1957) and Tietz(1986) using commercial kits from Biolabo (France).

Determination of plasma levels of triglycerides, total cholesterol, LDL-cholesterol and HDL-cholesterol: were performed according to the method described by Vassault et al. (1986), Rifai et al. (1999) and Fruchart(1982) using kits supplied by Greiner Diagnostic, Germany.

Atherogenic index was calculated according to Grundy et al. (1987) as follows: Atherogenic index = Total cholesterol / HDL-C.

\section{Evaluation of Mitochondrial NAD'inHepatic tissue:-}

Mitochondrial isolation from hepatic tissues which were stored frozen at $-80^{\circ} \mathrm{C}$ till the day of $\mathrm{NAD}^{+}$determination, was performed according to Saleh and Saleh (2010). Hydrolysis of mitochondrial nicotinamide adenine dinucleotide $\left(\mathrm{NAD}^{+}\right)$directly reflects mitochondrial pores opening. The $\mathrm{NAD}^{+}$was measured after perchloric acid extraction. In the case of isolated mitochondria, $0.1 \mathrm{ml}$ of $21 \%$ (v/v) perchloric acid was added to $1 \mathrm{mg}$ of protein/ml suspensions. The concentration of $\mathrm{NAD}^{+}$in the percholric acid extract of the hepatic mitochondria was measured using an alcohol dehydrogenase reaction. The reaction mixture contained $1000 \mu \mathrm{l}$ of buffer-substance $(0.1 \mathrm{M}$ Tris acetate [pH 8.8] and $0.5 \mathrm{M}$ ethanol), $100 \mu \mathrm{l}$ of the tissue extract neutralized and $20 \mu \mathrm{l}$ of alcohol dehydrogenase. The reaction was initiated by enzyme addition and change of absorbance at $340 \mathrm{~nm}$ recorded by a spectrophotometer (Behring Werke AG, Marburg, and West-Germany). 
RNA preparation and real-time $q \mathrm{PCR}$ analysis:-

Total mRNA was extracted from liver tissues using RNeasy kits with spin-column DNase digestion (Qiagen). Purity and concentration were determined with a Nanodrop 1000 spectrophotometer (Thermo Scientific). One $\mu \mathrm{g}$ of RNA was used to synthesize cDNA with a QuantiTect Rev. Transcription Kit (Qiagen) and diluted to $10 \mathrm{ng} / \mu \mathrm{L}$. Expression of mRNA was determined using RT2 ${ }^{2}$ PCR Primer Assay for rat stearoyl-Coenzyme-A desaturase 1 (SCD1)catalogue no: 330001(Qiagen) and SYBR green RT ${ }^{2}$ SYBR Green ROX ${ }^{\mathrm{TM}}$ qPCR Mastermix on an Applied Biosystems Step One Plus RT-PCR system. PCR mix for one reaction Component Volume RT ${ }^{2}$ SYBR Green Mastermix was prepared as follows $\left(12.5 \mu \mathrm{l}\right.$ cDNA synthesis reaction $1 \mu \mathrm{l} \mathrm{RT}{ }^{2} \mathrm{qPCR}$ Primer Assay (10 $\mu \mathrm{M}$ stock) 1 $\mu \mathrm{l}$ RNase-free water $10.5 \mu \mathrm{l}$ Total volume $25 \mu \mathrm{l}$. The PCR Cycling conditions were adjusted following the manufacture instruction. Cycling program: Initial activation step for $10 \mathrm{~min}$ at $95^{\circ} \mathrm{C}$ to activate HotStarTaq DNA Polymerase, cycling: (Denaturation for 15 seconds at $94^{\circ} \mathrm{C}$, annealing for 30 seconds at $60^{\circ} \mathrm{C}$, then extension for 30 seconds at $\left.70^{\circ} \mathrm{C}\right) \mathrm{X} 40$ cycles. PCR products werequantified fluorometrically using SYBR Green, and normalizedto the housekeeping gene ratglyceraldehyde-3-phosphate dehydrogenase (GAPDH)and relative to the control according to the following formula:

Target amount $=2-\Delta \Delta \mathrm{Ct}$

Where $\Delta \Delta \mathrm{Ct}=\{[\mathrm{Ct}$ (target gene) $-\mathrm{Ct}(\mathrm{GAPDH})]-[\mathrm{Ct}$ (control) $-\mathrm{Ct}$ (GAPDH control) $\}$.

Fold difference for gene expression was calculated as $2-\Delta \Delta \mathrm{CT}$ using the endogenous control genes (liver). The identity and purity of the amplified product were assessed by melting curve analysis at the end of amplification.

Statistical Analysis:-

All results in the present study were expressed as mean \pm SE of the mean. Statistical Package for the Social Sciences (SPSS, Inc., Chicago, IL, USA) program, version 20.0 was used. Differences were considered significant when $\mathrm{P} \leq$ 0.05 .

Ethics Committee:-

This study was approved by the Ethics Committee of Faculty of Medicine, Ain Shams University.

\section{Results:-}

The diabetic and vitamin D3 treated diabetic groups had significant rises in fasting blood glucose, fasting insulin, HbA1c levels and HOMA-IR compared to the control group, denoting the occurrence of type 2 diabetes mellitus. However, these glycemic parameters were significantly reduced in vitamin D3 treated diabetic group compared to the diabetic group. Vitamin D3 supplemented group (Positive control group) had insignificant changes in fasting blood glucose, fasting insulin, HbA1c levels and HOMA-IR compared to the control group (negative control), as shown in table (1).

Table 1:- Changes in fasting blood glucose (mg\%), fasting insulin level ( $\mu \mathrm{IU} / \mathrm{ml})$, HOMA-IR and HbA1c level $(\mathrm{gm} \%)$ in the different studied groups.

\begin{tabular}{|c|c|c|c|c|}
\hline Group & $\begin{array}{c}\text { Fasting blood } \\
\text { glucose }(\mathbf{m g} \%)\end{array}$ & $\begin{array}{c}\text { Fasting insulin } \\
\text { level }(\boldsymbol{\mu} \mathbf{I U} / \mathbf{m l})\end{array}$ & HOMA-IR & $\begin{array}{c}\text { HbA1c } \\
(\mathbf{g m} \%)\end{array}$ \\
\hline Control group (10) & 95.7 & 3.56 & 0.86 & 3.19 \\
& \pm 3.03 & \pm 0.18 & \pm 0.038 & \pm 0.11 \\
\hline Vitamin D3 & 89.8 & 3.6 & 0.8 & 3.27 \\
supplemented group (10) & \pm 2.89 & \pm 0.21 & \pm 0.053 & \pm 0.13 \\
$\mathbf{P}$ & $\mathrm{NS}$ & $\mathrm{NS}$ & $\mathrm{NS}$ & $\mathrm{NS}$ \\
\hline Diabetic group & 189.2 & 4.82 & 2.26 & 4.33 \\
$(\mathbf{1 0})$ & \pm 5.02 & \pm 0.19 & \pm 0.115 & \pm 0.13 \\
$\mathbf{P}$ & $<0.001$ & $<0.001$ & $<0.001$ & $<0.001$ \\
\hline Vitamin D3 treated & 110.1 & 4.17 & 1.14 & 3.93 \\
diabetic group (10) & \pm 2.43 & \pm 0.14 & \pm 0.051 & \pm 0.16 \\
$\mathbf{P}$ & $<0.01$ & $<0.05$ & $<0.01$ & $<0.001$ \\
$\mathbf{P *}$ & $<0.001$ & $<0.02$ & $<0.001$ & $<0.05$ \\
\hline
\end{tabular}

In parenthesis is the number of rats studied in each group.

Values are expressed as means \pm SEM. NS: Not significant.

P: Significance by LSD at $\mathrm{P}<0.05$ from the control group. 
$\mathrm{P}^{*}$ : Significance by LSD at $\mathrm{P}<0.05$ from the diabetic group.

Regarding liver functions, plasma AST and ALT levels and $\gamma$-GT activity in plasma were significantly increased in both diabetic (untreated and treated) groups compared to the control group, while they were significantly reduced in vitamin D3 treated diabetic group compared to the diabetic group. On the other hand, no-statistical significance was detected in these parameters in vitamin D3 supplemented group compared to control group, as shown in table (2).

Table 2:- Changes in AST (IU/mL) and ALT (IU/mL) levels and $\gamma$-GT activity (IU/L) in the different studied groups.

\begin{tabular}{|c|c|c|c|}
\hline Group & $\begin{array}{c}\text { AST } \\
(\mathbf{I U} / \mathbf{m L})\end{array}$ & $\begin{array}{c}\text { ALT } \\
(\mathbf{I U} / \mathbf{m L})\end{array}$ & $\begin{array}{c}\boldsymbol{\gamma} \text {-GT activity } \\
(\mathbf{I U} / \mathbf{L})\end{array}$ \\
\hline Control group (10) & 18.14 & 8.85 & 5.04 \\
& \pm 1.78 & \pm 1.19 & \pm 0.59 \\
\hline Vitamin D3 supplemented group (10) & 21.64 & 10.11 & 6.39 \\
$\mathbf{P}$ & \pm 1.55 & \pm 0.56 & \pm 0.49 \\
& $\mathrm{NS}$ & $\mathrm{NS}$ & $\mathrm{NS}$ \\
\hline Diabetic group & 36.49 & 36.79 & 23.67 \\
$\mathbf{( 1 0 )}$ & \pm 3.01 & \pm 5.04 & \pm 1.91 \\
$\mathbf{P}$ & $<0.001$ & $<0.001$ & $<0.001$ \\
\hline Vitamin D3 treated diabetic group (10) & 27.4 & 27.1 & 11.55 \\
$\mathbf{P}$ & \pm 2.91 & \pm 2.93 & \pm 1.38 \\
$\mathbf{P}^{*}$ & $<0.02$ & $<0.001$ & $<0.002$ \\
& $<0.02$ & $<0.05$ & $<0.001$ \\
\hline
\end{tabular}

In parenthesis is the number of rats studied in each group.

Values are expressed as means \pm SEM.

P: Significance by LSD at $\mathrm{P}<0.05$ from the control group.

$\mathrm{P}^{*}$ : Significance by LSD at $\mathrm{P}<0.05$ from the diabetic group.

NS: Not significant.

The diabetic group showed significantly elevated plasma levels of triglycerides, total cholesterol and LDLCholesterol, accompanied by significantly reduced plasma HDL-Cholesterol compared to the control group, whereas vitamin D3 treated diabetic group had significantly increased only plasma total cholesterol and LDL-Cholesterol levels compared to the control group. However, vitamin D3 treated diabetic group showed significantly decreased plasma levels of triglycerides, total cholesterol and LDL-Cholesterol accompanied by a significant rise of plasma HDL-Cholesterol compared to the diabetic group. Although atherogenic index was significantly elevated in untreated and treated diabetic groups compared to the control group, it was significantly decreased in vitamin D3 treated diabetic group compared to the diabetic group. Non-significant changes in lipid profile were present in vitamin D3 supplemented group compared to the control group, as shown in table (3) and fig.(1).

Table 3:- Lipid profile changes in the different studied groups.

\begin{tabular}{|c|c|c|c|c|c|}
\hline Group & $\begin{array}{c}\text { Triglycerides } \\
(\mathbf{m g} / \mathbf{d l})\end{array}$ & $\begin{array}{c}\text { Total } \\
\text { Cholesterol } \\
(\mathbf{m g} / \mathbf{d l})\end{array}$ & $\begin{array}{c}\text { LDL- } \\
\text { Cholesterol } \\
(\mathbf{m g} / \mathbf{d l})\end{array}$ & $\begin{array}{c}\text { HDL- } \\
\text { Cholesterol } \\
(\mathbf{m g} / \mathbf{d l})\end{array}$ & $\begin{array}{c}\text { Atherogenic } \\
\text { index }\end{array}$ \\
\hline $\begin{array}{c}\text { Control group } \\
(\mathbf{1 0})\end{array}$ & 40.18 & 79.06 & 34.53 & 39.96 & 2.002 \\
& \pm 2.82 & \pm 3.42 & \pm 1.78 & \pm 2.24 & \pm 0.079 \\
\hline Vitamin D3 & 39.86 & 73.41 & 32.11 & 37.39 & 1.987 \\
supplemented group & \pm 2.45 & \pm 2.12 & \pm 1.93 & \pm 1.55 & \pm 0.083 \\
$(\mathbf{1 0})$ & $\mathrm{NS}$ & $\mathrm{NS}$ & $\mathrm{NS}$ & $\mathrm{NS}$ & $\mathrm{NS}$ \\
$\mathbf{P}$ & 54.05 & 104.56 & 68.86 & 30.24 & 3.6 \\
Diabetic group (10) & \pm 3.55 & \pm 3.87 & \pm 3.84 & \pm 1.94 & \pm 0.278 \\
$\mathbf{P}$ & $<0.005$ & $<0.001$ & $<0.001$ & $<0.005$ & $<0.001$ \\
\hline Vitamin D3 treated & 41.54 & 93.46 & 50.49 & 38.44 & 2.432 \\
diabetic group (10) & \pm 2.92 & \pm 4.28 & \pm 2.47 & \pm 2.55 & \pm 0.159 \\
$\mathbf{P}$ & $\mathrm{NS}$ & $<0.01$ & $<0.001$ & $\mathrm{NS}$ & $\mathrm{NS}$ \\
$\mathbf{P *}$ & $<0.01$ & $<0.05$ & $<0.001$ & $<0.02$ & $<0.001$ \\
\hline
\end{tabular}


In parenthesis is the number of rats studied in each group.

Values are expressed as means \pm SEM. NS: Not significant.

P: Significance by LSD at $\mathrm{P}<0.05$ from control group.P*: Significance by LSD at $\mathrm{P}<0.05$ from the diabetic group.
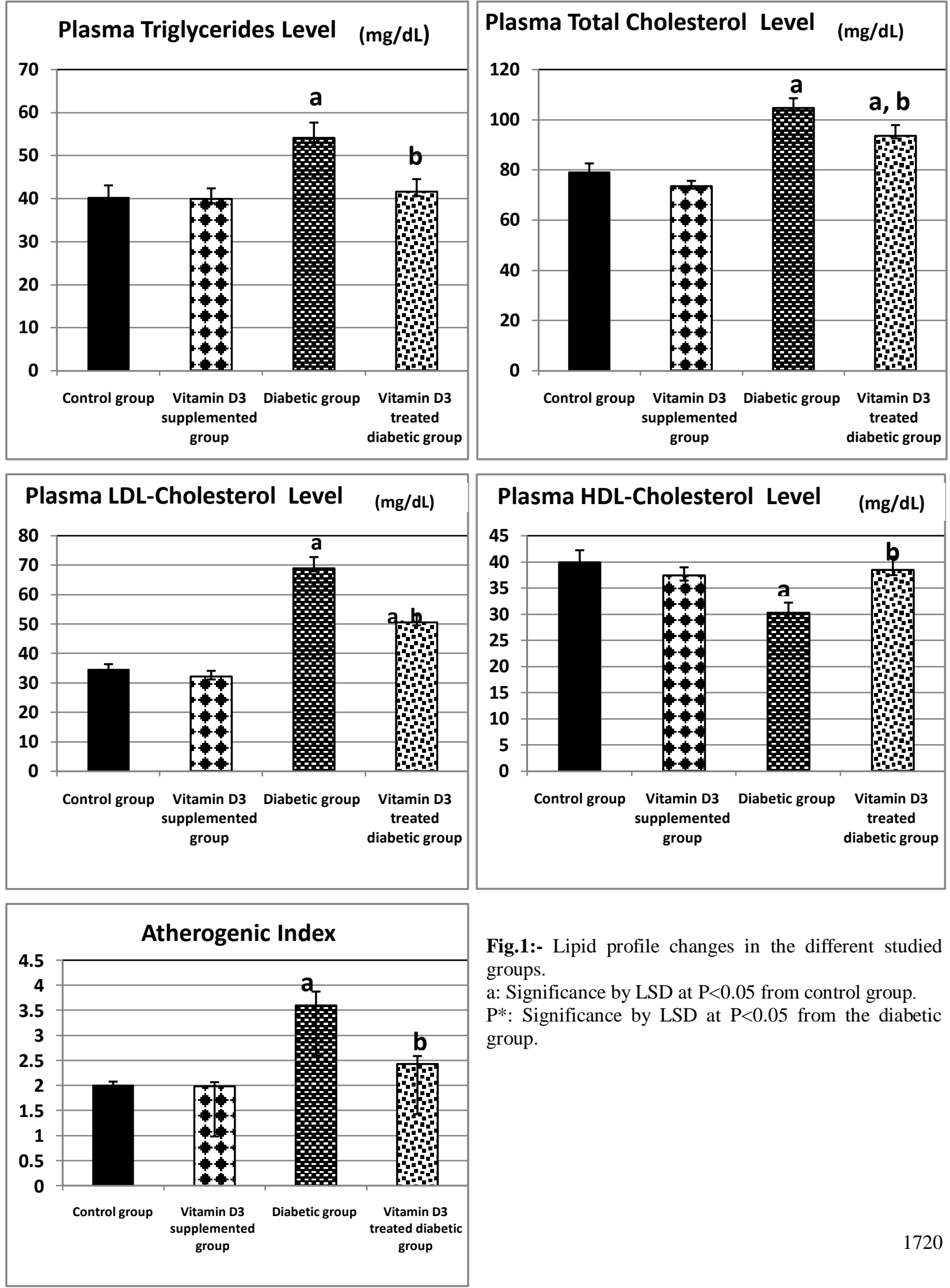

Fig.1:- Lipid profile changes in the different studied groups.

a: Significance by LSD at $\mathrm{P}<0.05$ from control group. $\mathrm{P}^{*}$ : Significance by LSD at $\mathrm{P}<0.05$ from the diabetic group. 
Similar levels of SCD1 gene expression was detected in Vitamin D3 supplemented group and control group with insignificant differences. However, the diabetic group showed downregulated SCD1 mRNA by 10 folds less than control group denoting that SCD1 mRNA levels and the enzyme activity in liver were strongly downregulated in both diabetic groups (treated and untreated). In addition, in vitamin D3 treated diabetic group, SCD1 mRNA level was significantly decreased compared to control group; however, it was significantly elevated compared to the diabetic group, as shown in table (4).

Table 4:- Changes of liver cell mitochondrial $\mathrm{NAD}^{+}$(nmol/mg tissue protein) and liver cell SCD1 gene expression $[($ fold $) / \mathrm{ul}]$ in the different studied groups.

\begin{tabular}{|c|c|c|}
\hline Group & $\begin{array}{c}\text { Mitochondrial NAD+ } \\
\text { (nmol/mg tissue protein) }\end{array}$ & $\begin{array}{c}\text { SCD1 } \\
\text { Gene expression } \\
\text { (fold)/ul }\end{array}$ \\
\hline $\begin{array}{c}\text { Control group } \\
(\mathbf{1 0})\end{array}$ & 7.52 & 0.768 \\
\pm 0.067 \\
\hline Vitamin D3 supplemented group (10) & \pm 0.97 & 0.865 \\
& 8.18 & \pm 0.031 \\
\hline Diabetic group (10) & \pm 1.14 & $\mathrm{NS}$ \\
\hline $\mathbf{N S}$ & 15.97 & 0.065 \\
& \pm 1.16 & \pm 0.017 \\
\hline Vitamin D3 treated diabetic group & $<0.001$ & $<0.002$ \\
$(\mathbf{1 0})$ & 10.48 & 0.412 \\
$\mathbf{P}$ & \pm 1.14 & \pm 0.051 \\
$\mathbf{P *}$ & $\mathrm{NS}$ & $<0.001$ \\
\hline
\end{tabular}

In parenthesis is the number of rats studied in each group.

Values are expressed as means \pm SEM.

P: Significance by LSD at $\mathrm{P}<0.05$ from control group.

$\mathrm{P}^{*}$ : Significance by LSD at $\mathrm{P}<0.05$ from the diabetic group.

NS: Not significant.

Liver cell mitochondrial $\mathrm{NAD}^{+}$was significantly elevated in the diabetic group compared to the control group, and was insignificantly changed in vitamin D3 treated diabetic and vitamin D3 supplemented groups compared to the control group. On the other hand, there was significant decline in liver cell mitochondrial $\mathrm{NAD}^{+}$in vitamin D3 treated diabetic group compared to the diabetic group, as shown in table (4).

\section{Discussion:-}

Induction of type 2 diabetes mellitus in rats was confirmed by assessment of biochemical indicators which includes; hyperglycemia, hyperinsulinemia and poor glycemic control. Poor glycemic control was evaluated by HbA1c, and elevated HOMA-IR as indicator for insulin resistance (Ahmad et al., 2016).

Vitamin D3 treated diabetic group showed reduction in hyperglycemia, hyperinsulinemia and insulin resistance compared to the diabetic group. These findings agree with the study of Talaei et al. (2013), who found that vitamin D3 supplementation could reduce insulin resistance in Type 2 diabetic patients.Obese persons, who might be diabetics, could have lowered circulating 25(OH) D levels (Bell et al. 1985; Wortsman et al. 2000), which could bedue to the storage of vitamin D3 and $25(\mathrm{OH})$ vitamin D3 in adipose tissue (Wortsman et al. 2000). Thus,Borissova et al. (2003) suggested that vitamin D3 supplementation could treat type 2 diabetes mellitus during the winter.

However, Vitamin D injection(Heshmat et al., 2011) and vitamin D intake did not change the glycemic control in the diabetics (Behradmanesh et al., 2011). Also, Boucher et al. (1995) found thatvitamin D caused elevated blood glucose level in diabetic patients compared to the pre-treatment value 8-12 weeks after a single vitamin D injection in a dose of $2500 \mathrm{mg}$, they attributed the failure to correct diabetes by vitamin D in their study to the moderate increase of $25(\mathrm{OH})$ plasma vitamin $\mathrm{D}$ levels to be only $25 \mathrm{nmol} / \mathrm{L}$.

These protective vitamin D3 effects in diabetes mellitus could be due to its anti-inflammatory properties, or it might affect calcium and phosphorus metabolism facilitating insulin secretion and synthesis via $\beta$-cell calcium-dependent 
endopeptidases (Chiu et al., 2004). Calcium, also, is essential for $\beta$-cell glycolysis, which plays a role in signaling circulating glucose concentration(Boucher, 1998). Moreover, vitamin D could upregulate the insulin receptor gene(Maestro et al., 2002). These mechanisms could be supported by presence of vitamin D receptors on pancreatic $\beta$ cells(Zittermann, 2006), and in skeletal muscle (Simpson et al., 1985), expression of $1 \alpha$ hydroxylase in pancreatic $\beta$ cells(Bland et al., 2004) andpresence of vitamin D response element insulin receptor genes transcription (Maestro et al., 2002).

In the current study, the diabetic group was dyslipidemic evidenced by elevated plasma levels of triglycerides, total cholesterol, LDL-Cholesterol and atherogenic index accompanied by reduced plasma HDL-Cholesterol compared to the control group. Similar findings were reported in Ahmad et al. (2016). Also,Kudchodkar et al. (1988) reported that elevated plasma triglycerides levels might be commonly present in diabetes mellitus, and could be due to deficient lipoprotein lipaseactivity (Bruan and Severson, 1992). Thus, Lopes-Virella et al. (1983) found that insulin treatment in diabetics lowered plasma triglycerides levels by normalizing lipoprotein lipase levels.

Treatment of type 2 diabetes mellitus by vitamin D, in this study, ameliorated the diabetes mellitus induced dyslipidemia, manifested by lowered plasma levels of triglycerides, total cholesterol, LDL-Cholesterol and atherogenic index together with higher plasma HDL-Cholesterol compared to the diabetic group. When comparing vitamin D3 treated diabetic group and the control group, only total cholesterol and LDL-Cholesterol were reduced. These findings were similar to the study of Al-Daghri et al. (2012), who found that vitamin D3 administration daily for 18 months caused lowered levels of total cholesterol and LDL cholesterol, without changes in levels of triglycerides and HDL cholesterol. Similarly, Shehab et al. (2012) foundsignificant correlations with total cholesterol, LDL-cholesterol with vitamin D. This lipolytic actions of vitamin D3 could be due to upregulation of lipolytic enzymes hormone sensitive and lipoprotein lipases induced by 1, 25(OH)2D (Huang et al., 2013).

However, the lipid lowering effect of vitamin D3 in the diabetic group, in the present study, disagree with the study ofBreslavsky et al. (2013), who found no changes in levels of total cholesterol, LDL cholesterol, HDL cholesterol and triglycerides in type 2 diabetics despite vitamin D administration for 12 months. The discrepancy of vitamin D effects on lipid profile in type 2 diabetes mellitus was attributed to the requirement of $25(\mathrm{OH}) \mathrm{D}$ levels to be higher than $28-32 \mathrm{ng} / \mathrm{ml}$ in the type 2 diabetic persons to induce such possible extra-skeletal benefits of vitamin D (Hossein-nezhad and Holick, 2013).

The diabetic group had liver cell injury, evidenced by elevated plasma levels of AST, ALT and plasma $\gamma$-GT activity, which were in accordance to Hamadi et al. (2012). This damage could be due to the oxidative stress present in the diabetic group (Kakkar et al., 1998).Tangvarasittichai(2015) reported that increased glucose, free fatty acids (FFA) and insulin levels caused reactive oxygen species overproduction, increased oxidative stress and activate stress transduction factor pathways resulting to inhibited insulin activity and secretion causing the onset of type 2 diabetes mellitus.

Vitamin D3 treated diabetic group had lowered AST, ALT and $\gamma$-GT activity compared to the diabetic group, denoting hepato-protective effects of vitamin D3 which were similar to the study of George et al. (2012). They reported that the restoring effect of vitamin D3 could be mediated through vitamin D receptor modulation, thereby improving signal transduction and controlling free radicals in the liver of diabetic rats, suggesting a potential role for vitamin D3 in the treatment of diabetes-associated hepatic complications. In addition, the active vitamin D's roles of improving the hepatic steatosis and hepatic insulin resistance could be mediated through its receptor-activated peroxisome proliferator-activated receptors- $\alpha$ (PPAR- $\alpha$ ) signaling pathway (Yin et al., 2012; Zhao et al., 2013).

The protective vitamin D3 effect against liver cell injury observed in the current study may be attributed to its lipid lowering effect. Similar explanation was reported by Yin et al. (2012), who found that vitamin D3 preventing effect against hepatic steatosis was due to inhibited lipogenesis and the elevated FFA oxidation in rat liver.

Liver cell mitochondrial $\mathrm{NAD}^{+}$, as an indicator of oxidative stress, was significantly elevated in the diabetic group compared to the control group. This new finding in type 2 diabetes mellitus could explain the oxidative stress present in diabetes mellitus, which was found in the study of Kakkar et al. (1998). They, also, suggested that oxidative stress could be the cause of development and progression of diabetes mellitus. The elevated $\mathrm{NAD}^{+}$in liver cells of diabetic group could be due to transient upregulated mitochondrial oxidative capacity in the liver, similar to 
the study on obese insulin-resistant persons with or without fatty liver resulting to oxidative stress (Koliaki and Roden, 2016).

The vitamin $\mathrm{D} 3$ treatment had decreased mitochondrial $\mathrm{NAD}^{+}$in treated diabetic group in the present study. This is in accordance to the study of Chang and Kim (2016), who found that $1,25(\mathrm{OH}) 2 \mathrm{D}$ treatment elevated NAD-toNADH ratio, and suggested that vitamin D could cause fat mobilization and reducing intracellular fat accumulation and increase lipolysis.

The elevated mitochondrial $\mathrm{NAD}^{+}$could be linked to higher plasma levels of liver enzymes present in the diabetic group. Maxwell et al. (1997) reported that diabetes mellitus could cause oxidative damage resulted from antioxidant protection defects, thereby many diabetic complications could be developed. Also, Alam et al. (2014) found that the antioxidant treatment of diabetic rats, which was quercetin, had lowered liver enzymes and oxidative stress markers. Thus, the hepato-protective effects of vitamin D3 in diabetes mellitus, observed in this study, assure the antioxidant and lipolytic effects of vitamin D3.

In addition, both diabetic and vitamin D3 treated diabetic groups showed downregulation of SCD1 m-RNA levels in liver cells. SCD1 enzyme has an important role in lipid metabolism and energy expenditure in mammals (Wang et al., 2008). SCD genes are regulated at the transcriptional level by the diet, hormones such as insulin and temperature (Wang et al., 2005). This could explain the changes present in SCD1 m-RNA levels in liver cells in both diabetic groups (treated and untreated).Moreover,Popeijus et al. (2008) reported that raised, rather than reduced, SCD1 mRNA levels could be negatively associated with insulin resistance.

Droge(2002) mentioned that SCD-1 could cause fat storage when its activity is elevated, and towards oxidation, when become less active. Hence elevated fatty acid oxidation could raise toxic free radicals levels, the presence of SCD1 downregulation and higher mitochondrial $\mathrm{NAD}^{+}$in liver cells, in this study, could be linked together.

It was reported by Ntambi et al.(2002) that diabetic dyslipidemia could be attributed to downregulated SCD1 mRNA levels in liver cells. Mice with whole-body SCD1 deficiency were lean, and developed severe hypercholesterolaemia and a marked decrease in HDL cholesterol levels when they were fed a low-fat, highcarbohydrate diet (Flowers et al., 2006). Also, the downregulated SCD1 in liver cells could be linked to the insulin resistance in the diabetic group. Roden(2006) reported that the hepatic SCD1 activity index was correlated with insulin sensitivity. Stefan et al. (2008) mentioned thatSCD1 could affect insulin sensitivity via regulation of fat accumulation in the liver. High liver fat could cause hepatic and skeletal muscle insulin resistance (Stefan et al., 2006), thus hepatic SCD1 activity could regulate skeletal muscle insulin sensitivity(Stefan et al., 2008).

In this study, the novel finding of upregulated SCD1 m-RNA levels in liver cells in vitamin D3 treated diabetic group compared to the diabetic group, could explain the decreased insulin resistance. This suggestion could be supported by high SCD1 activity protected both from obesity and from palmitate-induced insulin resistance and lipotoxicity(Busch et al., 2005). Moreover,Foster (2004) reported thata marked stimulation of the transcription factor carbohydrate-responsive element binding protein were present in the fed state activating the genes of fatty acid and triglyceride synthesis. Thus, SCD-1 is lipogenic via more than one pathway. In the fasting state, SCD-1 levels decreased due to insulin decrease and glucagon increase. This, also, could explain the presence of downregulated SCD1 in liver cell in the vitamin D3 treated diabetic group compared to the control group.

Therefore, the vitamin D3 ameliorated liver damage, dyslipidemia, downregulation of liver cell SCD1 and controlled elevated liver cell mitochondrial $\mathrm{NAD}^{+}$in type 2 diabetes mellitus.

\section{Conclusion:-}

Diabetes mellitus resulted in deteriorated liver functions in diabetic rats and downregulation of SCD1 m-RNA levels in liver cells. Such changes could be caused by oxidative stress and were alleviated by vitamin D3 treatment.

\section{Conflict of Interest:-}

The authors declared no conflict of interest in this study.

\section{Funding:-}

This study was funded only by the authors, without any source of funding from any institute. 


\section{References:-}

1. Ahmad H, Ahmed Z, Khan R. Effect of Chromium Picolinate Supplementation on Diabetic Profile and Nutritional Status of the Type-2 Diabetic Adult Population - A Randomized Controlled Trial. J. Food and Nutrition Research. 4(8): 535-542, 2016

2. Alam MM, Meerza D, Naseem I. Protective effect of quercetin on hyperglycemia, oxidative stress and DNA damage in alloxan induced type 2 diabetic mice. Life Sci 109(1):8-14, 2014

3. Al-Daghri N, Alkharfy K, Al-Othman A, El-Kholie E, Moharram O, Alokail M, Al-Saleh Y, Sabico S, Kumar S, Chrousos G. Vitamin D supplementation as an adjuvant therapy for patients with T2DM: an 18-month prospective interventional study. CardiovascDiabetol 11: 85, 2012.

4. Behradmanesh S, Roudini K, Baradaran A. Effect of Supplementary Vitamin D on Improvement of Glycemic Parameters in Patients with Type 2 Diabetic. J Isfahan Med Sch 29(151):1098-1105, 2011.

5. Bell NH, Epstein S, Greene A, Shary J, Oexmann MJ, Shaw S. Evidence for alteration of the vitamin Dendocrine system in obese subjects. J ClinInves 76: 370-373, 1985.

6. Bland R, Markovic D, Hills CE, Hughes SV, Chan SL, Squires PE, Hewison M. Expression of 25hydroxyvitamin D3-1alpha-hydroxylase in pancreatic islets. J Steroid BiochemMolBiol 89-90(1-5):121-125, 2004.

7. BorissovaAM ,Tankova T, Kirilov G, Dakovska L, Kovacheva R. The effect of vitamin D3 on insulin secretion and peripheral insulin sensitivity in type 2 diabetic patients. Int. J. Clini. Pra. 57(4):258-261, 2003.

8. Boucher BJ. Inadequate vitamin D status. Does it contribute to the disorders comprising syndrome " $\mathrm{X}$ ". Br $\mathrm{J}$ Nutr 79: 315-327, 1998.

9. Boucher BJ, Mannan N, Noonan K, Hales CN, Evans SJ. Glucose intolerance and impairment of insulin secretion in relation to vitamin D deficiency in East London Asians.Diabetologia 38: 1239-1245, 1995.

10. Breslavsky A, Frand J, Matas Z, Boaz M, Barnea, Z, Shargorodsky M. Effect of high doses of vitamin D on arterial properties, adiponectin, leptin and glucose homeostasis in type 2 diabetic patients. ClinNutr 32: 970975, 2013.

11. BruanJEA and Severson DL. Lipoprotein lipase released from myocytes is increased by decavandate but not insulin. Am. J. of Physiol 262(E): 663-E670, 1992.

12. Busch AK, Gurisik E, Cordery DV, Michelle Sudlow, Gareth S, Denyer D, Labutt R, Hughes WE, Biden TJ. Increased fatty acid desaturation and enhanced expression of stearoyl coenzyme A desaturase protects pancreatic beta-cells from lipoapoptosis. Diabetes 54:2917-2924, 2005.

13. Chang E and Kim Y. Vitamin D decreases adipocyte lipid storage and increases NAD-SIRT1 pathway in 3T3L1 adipocytes. Nutrition 32: 702-708, 2016.

14. Chiu KC, Chu A, Go VLW, Saad MF. Hypovitaminosis D is associated with insulin resistance and $\beta$ cell dysfunction. Am J ClinNutr 79: 820-825, 2004.

15. Danaei G, Finucane MM, Lu Y, Singh GM, Cowan MJ, Paciorek CJ, Lin JK, Farzadfar F, Khang YH, Stevens GA, Rao M, Ali MK, Riley LM, Robinson CA, Ezzati M. National, regional, and global trends in fasting plasma glucose and diabetes prevalence since 1980: systematic analysis of health examination surveys and epidemiological studies with 370 country-years and 2.7 million participants. Lancet 378:3-40, 2011.

16. DeLuca HF and Cantorna MT. Vitamin D: its role and uses in immunology. FASEB J 15:2579-2585, 2001.

17. Dobrzyn $\mathrm{P}$ and Dobrzyn A. Stearoyl-CoA desaturase: a new therapeutic target of liver steatosis. Drug Development Research 67(8): 643-650, 2006.

18. Droge W. Free radicals in the physiological control of cell function.Physiol. Rev. 82: 47-95, 2002.

19. Flier JS, Khan CR, Roth J. Receptor, anti-receptor antibodies and mechanisms of insulin resistance. New Engl. J Med. 300: 413-419, 1979.

20. Flowers MT, Groen AK, Oler AT, Keller M, Choi Y, Schueler KL, Richards OC, Lan H, Miyazaki CM, KuipersF, Kendziorski CM, Ntambi JM, Attie AD. Cholestasis and hypercholesterolemia in SCD1-deficient mice fed a low-fat, high carbohydrate diet. J Lipid Res 47:2668-2680, 2006.

21. Foster DW. The Role of the Carnitine System in Human Metabolism Annals of the New York Academy of Sciences 1033:1-16, 2004.

22. Fruchart JC. Separation of low density lipoproteins and determination of cholesterol and phospholipids bound to this fraction. Rev. Fr. Des laboratories 103: 7-17, 1982.

23. George N, Kumar TP, Antony S, Jayanarayanan S. Effect of vitamin D3 in reducing metabolic and oxidative stress in the liver of streptozotocin-induced diabetic rats. British journal of Nutrition 108(8): 1410-1418, 2012.

24. Giacco F and Brownlee M .Oxidative stress and diabetic complications Circ Res. 107(9): 1058-1070, 2010.

25. Gregori S, Giarratana N, Smiroldo S, Uskokovic M, Adorini L. A 1alpha, 25-dihydroxyvitamin D(3) analog enhances regulatory T-cells and arrests autoimmune diabetes in NOD mice. Diabetes 51: 1367-1374, 2002. 
26. Grundy SM, Greenland P, Herd A, Huebsch JA, Jones RJ, Mitchell JH, Schlant RC.Cardiovascular and risk factor evaluation of healthy American adults. A statement for physicians by an Ad Hoc Committee appointed by the Steering Committee, American Heart Association. Circulation 75: 1340A-1362A, 1987.

27. Hamadi N, Mansour A, Hassan MH, Khalifi-Touhami F, Badary O. Ameliorative effects of resveratrol on liver injury in streptozotocin-induced diabetic rats. J BiochemMolToxicol 26(10):384-92, 2012.

28. Heshmat R, Tabatabaee O, Moradzade K, Abasszade S. The effect of parenteral vitamin D supplementation on insulin resistance and anthropometric factors in patients with diabetes type 2. Iran J Diabetes Lipid Disord 10(5):492-501, 2011.

29. Holick MF. Vitamin D: importance in the prevention of cancers, type 1 diabetes, heart disease, and osteoporosis. Am J ClinNutr; 79: 362-371, 2004.

30. Holland B and Welch A. Hormone in insulin resistance of abdominal obesity: cause or effect? The composition of food 5:115, 1992.

31. Hossein-nezhad A and Holick M. Vitamin D for health: a global perspective. Mayo Clin Proc 88: 720-755, 2013.

32. Huang Y, Li X, Wang M, Ning H, Lima A, Li Y, Sun C. Lipoprotein lipase links vitamin D, insulin resistance, and type 2 diabetes: a cross-sectional epidemiological study. CardiovascDiabetol 12:17, 2013.

33. Jeppsson JO, Kobold U, Barr J, Finke A, Hoelzel W, Hoshino T, Miedema K, Mosca A, Mauri P, Paroni R, Thienpont L, Umemoto M, Weykamp C. Approved IFCC Reference Method for the Measurement of HbA1c in Human Bl. Cl. Chem and Lab Med. 40(1):78-89, 2002.

34. Kakkar R, Mantha SV, Radhi J, Prasad K, Kalra J. Increased oxidative stress in rat liver and pancreas during progression of streptozotocin- induced diabetes. ClinSci 94:623-632, 1998.

35. Koliaki C and Roden M. Alterations of mitochondrial function and insulin sensitivity in human obesity and diabetes mellitus. Annual Review of Nutrition 36: 337-367, 2016.

36. Kudchodkar BJ, Lee JC, Lee SM, DiMarco NM, Lacko AG. Effect of cholesterol homeostasis in diabetic rats. Journal of Lipid Research 29: 1272-1287, 1988.

37. Lopes-Virella MF, Stone P, Ellis S, ClowellJA.Cholesterol determination in high-density lipoproteins separated by three different methods. Clin. Chem. 23: 882, 1977.

38. Luong K, Nguyen LTH, Nguyen DNP. The role of vitamin D in protecting type 1 diabetes mellitus. Diabetes Metab Res Rev 21: 338-346, 2005.

39. Maestro B, Davila N, Carranza MC, Calle C: Identification of a Vitamin D response element in the human insulin receptor gene promoter. J Steroid BiochemMolBiol 2003, 84(2-3):223-230.

40. Maestro B, Molero S, Bajo S. Transcriptional activation of the human insulin receptorgene by 1, 25dihydroxyvitamin $\mathrm{D}(3)$. Cell bio-chemfunct 20:227-232, 2002.

41. Mathieu C, Gysemans C, Guilietti A, Bouillon R. Vitamin D and diabetes. Diabetologia 48: 1247-1257, 2005.

42. Maxwell SRJ, Thomason H, Sandler D, Leguen C, Baxter MA, Thorpe GHG, Jones AF, Barnett AH. Antioxidant status in patients with uncomplicated insulin-dependent and non-insulin-dependent diabetes mellitus. European J of ClinInves 27(6):484-490, 1997.

43. Miyazaki M and Ntambi JM. Role of stearoyl-coenzyme A desaturase in lipid metabolism. Prostaglandins, Leukotrienes and Essential Fatty Acids 68(2) 113-121, 2003.

44. Ntambi JM, Miyazaki M, Stoehr JP, Lan H, Kendziorski CM, Yandell BS, Song Y, Cohen P, Friedman JM, Attie AD. Loss of stearoyl- CoA desaturase- 1 function protects mice against adiposity. Proc Natl AcadSci USA 99(17):11482-11486, 2002.

45. Ogunkolade BW, Boucher BJ, Prahl JM, Bustin SA, Burrin JM, Noonan K, North BV, Mannan N, McDermott MF,Deluca HF, Hitman GA. Vitamin D receptor (VDR) mRNA and VDR protein levels in relation to vitamin D status, insulin secretory capacity, and VDR genotype in Bangladeshi Asians. Diabetes; 51: 2294-2300, 2002.

46. Ortlepp JR, Metrikat J, Albrecht M, Von Korff A, Hanrath P, Hoffmann R. The vitamin D receptor gene variant and physical activity predicts fasting glucose levels in healthy young men. Diabet Med 20: 451-454, 2003.

47. Palomer X, González-Clemente JM, Blanco-Vaca F, Mauricio D. Role of vitamin D in the pathogenesis of type 2 diabetes mellitus. Diabetes, Obesity and Metabolism 10(3):185-197, 2008.

48. Popeijus HE, Saris WHM, Mensink RP. Role of stearoyl-CoA desaturases in obesity and the metabolic syndrome. Int. J. of Obesity 32:1076-1082, 2008.

49. Reitman S. and Frankel S.A colorimetric method for determining serum glutamic oxaloacetic and glutamic pyruvic transminases. Am. J. Clin. Pathol. 28: 56-63, 1957.

50. Rifai N, Bachorik PS, and Albers JJ.Lipids, lipoproteins and apolipoproteins. In: Burtis CA, Ashwood ER, Tietz (3rd edn). W.B Saundes, Philadelphia, 809-861, 1999. 
51. Roden M. Mechanisms of disease: hepatic steatosis in type 2 diabetes pathogenesis and clinical relevance. Nat ClinPractEndocrinolMetab 2:335-348, 2006.

52. Saleh NK, Saleh HA.Protective effects of vitamin E against myocardial ischemia/reperfusion injury in rats. Saudi Med J 31(2): 142-147, 2010.

53. Salgado ALF, de Carvalho L, Oliveira AC, Nascimento VN, Vieira JG, Parise ER. Insulin resistance index (HOMA-IR) in the differentiation of patients with non-alcoholic fatty liver disease and healthy individuals, Arq. Gastroenterol. 47 (2):165-169, 2010.

54. Shehab D, Al-Jarallah K, Mojiminiyi OA, Al Mohamedy H, Abdella NA. Does Vitamin D deficiency play a role in peripheral neuropathy in Type 2 diabetes? Diabet. Med. 29: 43-49, 2012.

55. Shulman GI. Cellular mechanisms of insulin resistance. J. Clin. Invest. 106: 171-176, 2000.

56. Simpson RU, Thomas GA, Arnold AJ.Identification of 1, 25-dihydroxyvitamin D3 receptors and activities in muscle. J Biological Chemistry 260(15):8882-8891, 1985.

57. Srinivasan K., Viswanad B., Asrat L., Kaul C.L., and Ramarao P. (2005): Combination of high-fat diet-fed and low-dose streptozotocin-treated rat: a model for type 2 diabetes and pharmacological screening, Pharmacol Res;. 52(4):313-320.

58. Stefan N, Hennige AM, Staiger H, Machann J, Schick F, Krober SM, Machicao F, Fritsche A, Haring H. Alpha2-Heremans-Schmid glycoprotein/fetuin-A is associated with insulin resistance and fat accumulation in the liver in humans. Diabetes Care 29:853-857, 2006.

59. Stefan N, Peter A, Cegan A, Staiger H, Machann J, Schick F, Claussen CD, Fritsche A, Häring HU and Schleicher E. Low hepatic stearoyl-CoA desaturase 1 activity is associated with fatty liver and insulin resistance in obese humans. Diabetologia 51:648-656, 2008.

60. Stene LC, Ulriksen J, Magnus P, Joner G. Use of cod liver oil during pregnancy is associated with lower risk of type 1 diabetes in the offspring. Diabetologia43: 1093-1098, 2000.

61. Talaei A, Mohamadi M, Adgi Z. The effect of vitamin D on insulin resistance in patients with type 2 diabetes.Diabetology\& Metabolic Syndrome 5:8, 2013.

62. Tangvarasittichai S. Oxidative stress, insulin resistance, dyslipidemia and type 2 diabetes mellitus. World $\mathbf{J}$ Diabetes 6(3): 456-480, 2015.

63. Tietz NW. Textbook of clinical chemistry, W.B. Saunders co London, 1986.

64. Vassault A, Grafmeyer D, Naudin C, Dumont GR, Bailly M. Protocole de validation de techniques. Ann Bio Clin 44: 679-685, 1986.

65. Wang J, Yu L, Schmidt RE, Su C, Huang X, Gould K, Cao G. Characterization of HSCD5, a novel human stearoyl-CoA desaturase unique to primates. BiochemBiophys Res Commun 332: 735, 2005.

66. Wang J, Yu L, Wang H, Gao Y, SchrementiJP,Porter RK, Yurek DA, Kuo M, Suen C, Cao G, Bean JS, Kauffman RF, Qian Y. Identification and characterization of Hamster Stearoyl-Co a desaturase isoforms. Lipids 43: 197, 2008.

67. Wortsman J, Matsuoka LY, Chen TC, Lu Z, Holick MF. Decreased bioavailability of vitamin D in obesity.Am J Clin Nut 72: 690-693, 2000.

68. Yang Y, Liu B, Gao L, Wang D, Chen Q, Wang Q, Song M.Effect of 1, 25-Dihydroxyvitamin D3 on triglyceride content and expressions of protein tyrosine phosphatase-1B in liver of type 2 diabetes mellitus rat. Int J ClinExp Med 9(6):9425-9430, 2016.

69. Yin Y, Yu Z, Xia M, Luo X, Lu X, Ling W. Vitamin D attenuates high fat diet-induced hepatic steatosis in rats by modulating lipid metabolism. Eur J Clin Invest 42: 1189-1196, 2012.

70. Zeitz U, Weber K, Soegiarto DW, Wolf E, Balling R, Erben RG. Impaired insulin secretory capacity in mice lacking a functional vitamin D receptor. FASEB J 17:509-511, 2003.

71. Zhang J, Huang Y, Hou T, Wang Y. Hypoglycemic effect of Artemisia sphaerocephalaKrasch seed polysaccharide in alloxan-induced diabetic rats. SWISS. MED. WKLY., 136: 529-532, 2006.

72. Zhao XQ, Quan L, Du GL, Xiao S, Lü WK, Zhu J. Protective effects and mechanisms of 1, 25(OH)2D3 on diabetes-induced liver injury in a streptozotocin-diabetic rat model. Zho-nghuaGanZang Bing ZaZhi 21: 778780, 2013.

73. Zittermann A. Vitamin $\mathrm{D}$ and disease prevention with special reference to cardiovascular disease.ProgBiophysMolBiol 92:39-48, 2006. 